\title{
Interaction of Government Bodies and Civil Society Institutions for Achieving Public Policy Goals
}

Submitted 30/05/20, $1^{\text {st }}$ revision 12/06/20, $2^{\text {nd }}$ revision 10/07/20, accepted 30/07/20

\author{
Svitlana V. Onyshchuk ${ }^{1}$, Viktoriia D. Filippova ${ }^{2}$, Oksana A. Nosyk ${ }^{3}$, \\ Oleksandra B. Vasylchyshyn ${ }^{4}$, Valentyna P. Iakobchuuk ${ }^{5}$
}

\begin{abstract}
:
Purpose: The purpose of the scientific article is to study the peculiarities of the interaction of government and civil society institutions for achieving public policy goals.

Design/Methodology/Approach: This study is based on the study of theoretical and practical experience of interaction between government agencies and civil society institutions in order to achieve public policy goals in the context of processing a number of documents and analyzing current trends in cooperation.

Findings: It was found that in Ukraine the interaction between the authorities and civil society institutions in the context of achieving state policy goals involves the participation of civil society institutions in law enforcement, rule-making and law-enforcement functions of the country. It is proved that mutual trust between the authorities and civil society institutions should be based on the effectiveness of cooperation between them, and the key to a successful dialogue should be a public initiative.

Practical Implications: The study shows that the prospect of further cooperation between government agencies and civil society institutions in the context of achieving public policy goals is to eliminate the problems and negative factors identified in the article that hinder the implementation of such cooperation.

Originality/Value: The research conducted in the article indicates that mutual trust between the authorities and civil society institutions should be based on the effectiveness of cooperation between them and the key to a successful dialogue should be a public initiative.
\end{abstract}

Keywords: Civil society institutions, state policy, cooperation, public organizations, EU.

JEL Codes: D7, D73, D78, C5, C54.

Paper type: Research article.

\footnotetext{
${ }^{I}$ Associate Professor, Ivano-Frankivsk Regional State Administration, Ivano-Frankivsk, 76000,

Ukraine, E-mail: svikana@meta.ua

${ }^{2}$ Associate Professor, Kherson National Technical University, Kherson, 73008, Ukraine,

E-mail: filippova_vd@ukr.net

${ }^{3}$ Associate Professor, Kharkiv Regional Institute of Public Administration of the National Academy of

Public Administration attached to the Office of the President of Ukraine, Kharkiv, 61001, Ukraine,

E-mail: kadri_gu@ukr.net

${ }^{4}$ Professor, Ternopil National Economic University, Ternopil,46009, Ukraine,

E-mail: volexandra@gmail.com

${ }^{5}$ Professor, Zhytomyr National Agroecological University, Zhytomyr, 10008, Ukraine,

E-mail: valentyna.iakobchuk@gmail.com
} 


\section{Introduction}

Today, the success of the implementation of public policy goals primarily depends on the activities of public authorities. However, the research has shown that civil society institutions also play an important role in the implementation of public policy in the context of transforming goals into public programs and practical actions.

The modern experience of the relationship between the authorities and the institutions of civil society shows the next fact. The main component of a powerful state governed by the rule of law is a developed civil society that operates at a high level. This makes it clear that the development of the state largely depends on the development of civil society in the country.

So, based on the relevance of the development of civil society in the context of cooperation with the authorities, the aim of this scientific article is to study the peculiarities of the interaction between government and civil society institutions for achieving public policy goals.

\section{Literature Review}

In the context of revealing the theoretical features of the interaction of government and civil society institutions for achieving public policy goals should consider the scientific achievements of scientists who specialize in the study and thorough study of this issue.

Therefore, Pavliuk (2013) notes that the key feature of the interaction between government agencies and civil society institutions is the provision of public consultations through specially created public councils by the executive authorities.

At the same time, Gavkalova and Gruzd (2014) studied the interaction of public authorities and civil society institutions and note that the process of such interaction, as well as the results of such process, is influenced by a number of factors such as:

1) the degree of public confidence in the authorities, particularly in the government and politicians;

2) the level of favoritism in decisions made by officials;

3) the level of rationality of administrative regulation;

4) the level of efficiency of the legal system in the context of regulation and settlement of disputes;

5) the level of the legal system and its efficiency in the context of appealing disputes that occur on a regular basis;

6) the level of transparency of activities and fulfillment of functions by public authorities. 
In addition, Mesiuk (2018) emphasizes that one of the directions of interaction between government agencies and civil society institutions is the integration of Ukraine into the European Economic Area. Both the role of government and the role of civil society institutions are quite important in solving the above problem. However, speaking about the authorities, the scientists know that European integration is a key strategic task of Ukraine.

At the same time, the involvement of civil society institutions in this process depends on their confidence in European integration reforms. Taking into account that the authorities, in the context of ensuring interaction with civil society institutions, are required to solve problems such as to overcome corruption, to demonstrate real achievements of the transition to the European foreign economic vector of development, and to resist the negative impact on society (Mesiuk, 2018).

Karmazina (2013) considers the issue of interaction between the authorities and civil society institutions and presents a number of recommendations that will help to eliminate the problems that stand in the way of such interaction, in particular it is necessary:

1) to develop and implement a system of monitoring the condition and peculiarities of the response of public authorities to the results of research and examinations conducted by civil society institutions in order to reduce corruption of public authorities and stop lack of action in government;

2) to publish information in government reports concerning the results of public consultations;

3) to develop and implement a strategy for providing civil education;

4) to publish in advance the adopted draft laws and other normative legal acts concerning the observance and provision of constitutional rights, freedoms, duties and interests of citizens;

5) to ensure the responsibility of the authorities and officials of these bodies for violating the requirements of current legislation governing the organization of civil society.

At the same time, Liasota (2018) notes that one of the main ways of interaction between the authorities and civil society institutions is cooperation. In this work, the scientist also emphasizes that the main task of the state in the face of the authorities is to ensure the rights and freedoms of all citizens and everyone. However, as the conducted analysis in the article shows, today there is not any sufficiently favorable relationship between the authorities and civil society institutions, because the interaction between these entities is only at the initial stage of cooperation (Liasota, 2018).

The issue of achieving interaction between the authorities and civil society institutions is also clearly reflected in the studies of Melnyk (2015). In the study the scientist notes 
that the state represented by the government and civil society institutions cannot exist independently of each other. However, it should be noted that the country still has a significant influence on the institutions of civil society, as it guarantees and ensures the rights of a man and people in a whole, as well as reinforces the functions of the legislative, executive and judicial branches of government. However, we have to admit that the development of civil society institutions is not possible in conditions of political violence and tyranny but can occur only in a country governed by the rule of law and democracy (Melnyk, 2015).

At the same time, Novak-Kalyayeva and Raczynski (2019) note that one of the important features of society and its development is the rationalization of human rights. At the same time, informational and technological factors significantly influence on the relationship between the authorities and society. Scholars also underline that human rights emphasize the democratic potential that is primarily needed to ensure the development of society.

Instead, being based on the research presented by Akimova et al. (2020), it should be said that today an important aspect of cooperation between government and civil society institutions is to ensure socio-economic development of territories, based on the experience of the European Union in the context of implementing a number of development methods.

Such group of researchers as Pauly et al. (2016), studying the interaction of government and civil society, identify three key aspects of such interaction: 1) the ideological aspect, which is the emergence of a discussion between worldviews and political strategies of the decision-making authorities and civil society; 2) institutional aspect, where the focus is on formal rules, as well as on informal practice; 3) development strategies are taken into account which have been developed by civil society.

Spencer and Delvina (2018) consider one of the directions of cooperation between the authorities and civil society, which is the management of migration. Researchers are studying this issue on the example of cooperation between the governments of Europe and North America with the institutions of civil society in these countries.

At the same time, Romanenko (2016a) notes that Internet technologies play a leading role in the context of optimizing the relationship between public authorities and civil society institutions. Internet technologies are an important means of shaping public policy from the standpoint of the scientist, and their main function in this context is to ensure interactivity between civil society institutions and public authorities.

In addition, Romanenko (2016b) defines the role of communications in the formation of public authority. According to the scientist, communications allow to specify the 
functional and structural components of the activities of public authorities, as well as to properly disseminate information in the public administration system.

The team of scientists Kubiv et al. (2020), studying the issue of innovation potential, states that the country's innovation potential significantly affects the level of exports of high-tech goods. Therefore, public authorities in the framework of cooperation with civil society institutions need to include in the main aspects of cooperation the point of increasing the innovative potential of domestic products.

Bashtannyk et al. (2020), studying the basic principles of sustainable and financial and economic development of states, emphasize the significant impact on this process of 4 industrial revolutions. It should also be noted that the aspect of state development in the context of the Fourth Industrial Revolution should be considered as one of the defining areas of interaction between public authorities and civil society institutions.

\section{Research Methodology}

Theoretical and practical features of interaction of authorities with civil society institutions in the context of achieving public policy goals are presented through the usage of such general research methods as analysis, synthesis, concretization and analogy (to reveal the theoretical component of the study), as well as such empirical research methods such as observation method, modeling method, measurement method and description method (to reveal the practical component of the study).

The methodological basis of the study is based on the materials and data of the Dialogue of Civilizations (Dialogue of Civilizations Research Institute, 2017), Coordinating Council for Civil Society Development (2012), State Statistics Service of Ukraine (2020).

\section{Empirical Findings}

It is necessary to consider the main aspects of regulating the interaction of government and civil society institutions in the framework of achieving public policy goals in the context of disclosing the practical component of the study.

So, according to the Explanation of "Interaction of the State and Civil Society Institutions" submitted by the Ministry of Justice of Ukraine (Verkhovna Rada of Ukraine and Ministry of Justice of Ukraine, 2011), the main legal forms of interaction between government bodies and civil society institutions are:

- $\quad$ participation of civil society institutions in the lawn forcement function of the state, which, in turn, consists in:

a) the full transfer of powers of state bodies;

b) partial transfer of powers of state bodies; 
c) ensuring public control;

- participation of civil society institutions in the rule-making function of the state, which is to ensure the participation of civil society institutions in the development and discussion of a number of draft regulations;

- participation of civil society institutions in the lawn forcement function of the country, which provides for such processes as:

a) participation of civil society institutions in the implementation of the functions of public authorities in order to ensure the protection of civil order;

b) ensuring the right of civil society institutions to draw up protocols concerning administrative offenses;

c) participation of civil society institutions in the system of cessation of administrative offenses and crimes in the context of interaction with the police;

d) providing civil society institutions with an appropriate level of protection of public order in the context of interaction with law enforcement agencies.

As a result of the Explanation of "Interaction of the State and Civil Society Institutions" submitted by the Ministry of Justice of Ukraine (Verkhovna Rada of Ukraine and Ministry of Justice of Ukraine, 2011), it is noted that the interaction of authorities with civil society institutions is currently possible to provide only by a democratic state governed by the rule of law. It is so because civil society institutions must act as partners of the state and jointly ensure the implementation of rulemaking and law enforcement functions of the state. In addition, mutual trust between the authorities and civil society institutions should be based on the effectiveness of cooperation between them and the key to a successful dialogue should be a public initiative.

Based on the results presented in Dialogue of Civilizations Research Institute (2017), it should be underlined that today the interaction with civil society institutions is so multifaceted that it requires a lot of negotiations.

According to the information provided in Coordinating Council for Civil Society Development (2012), civil society institutions belong to private non-financial corporations and in many cases are registered in the Register of Non-Profit Institutions and Organizations.

According to the State Statistics Service of Ukraine (2020), in recent years the number of governing bodies of public organizations has been growing. So, in 2018, compared to 2014 , the number of governing bodies of public organizations in Ukraine increased by $19.6 \%$ (Figure 1). At the same time, in the period from 2014 to 2018, the largest quantitative increase of governing bodies of public organizations in Ukraine occurred in 2017 by $11.8 \%$, compared to 2016 . 
Figure 1. Governing bodies of public organizations in Ukraine, units

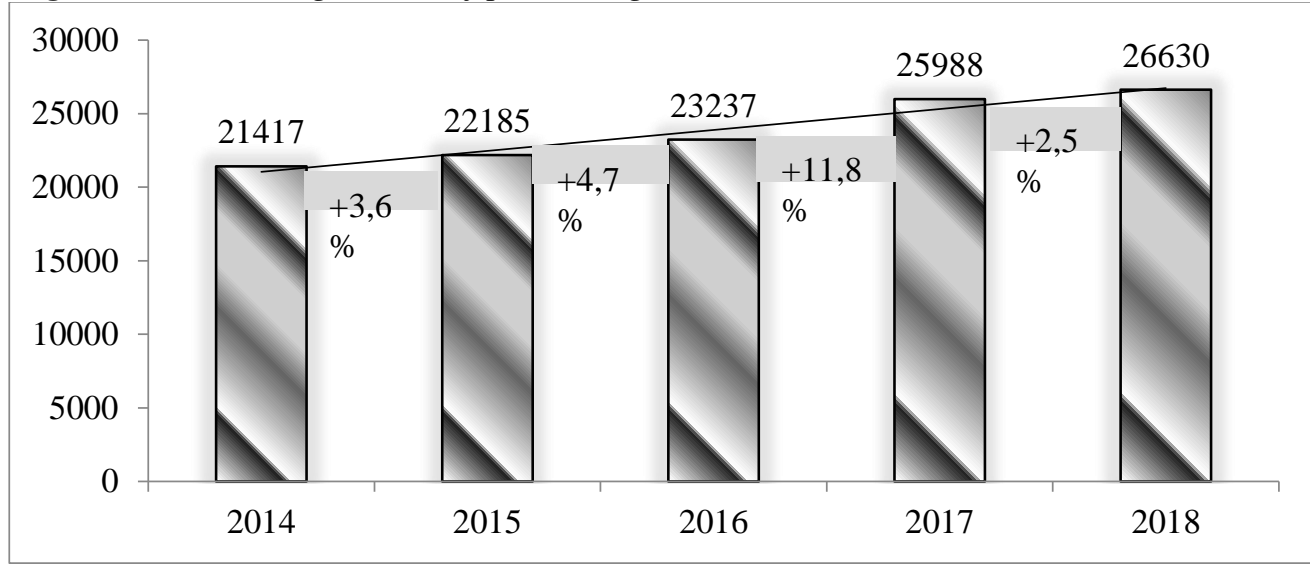

Source: State Statistics Service of Ukraine (2020).

If we are talking about the budget of public organizations in Ukraine, as it is shown by the State Statistics Service of Ukraine (2020), in the period from 2014 to 2018 there was a variation in the indicators of funds incoming in the budget of public organizations and indicators of funds usage from the budget of organizations. So, the trend line of indicators of funds incoming to the budget of public organizations shows that in 2016 there was a decrease in inflow of money to the budget by $1.7 \%$ (Figure 2). Instead, the trend line of indicators of money spending from the budget of public organizations showed a gradual increase in the amount of funds allocated from the budget of public organizations.

The results of the questionnaire, processed by experts and presented in (Krupnyk and Orlova, 2020), allow us to note the following. Public policy should be conducted only with the participation of civil society institutions from the public's point of view. Their participation should be regulated by law and based on European standards. In addition to this, the authorities should create appropriate conditions for public control over their activities. A high percentage of respondents have indicated that civil society institutions should be financed from state funds. Moreover, respondents have said that the country should create a special fund that could provide financial support to civil society institutions.

If we are talking about the problems that arise in the interaction of government and civil society institutions, a significant proportion of respondents in the questionnaire have indicated that the main problem is the lack of understanding of the benefits and role of civil society in public policy. In addition, a lot of respondents have said that government officials, including deputies, perceive civil society institutions as their competitors and therefore do not promote their development (Krupnyk and Orlova, 2020). 
Figure 2. Dynamics of change of funds incoming to the budget and money spending from the budget of public organizations in Ukraine, (thousand UAH)

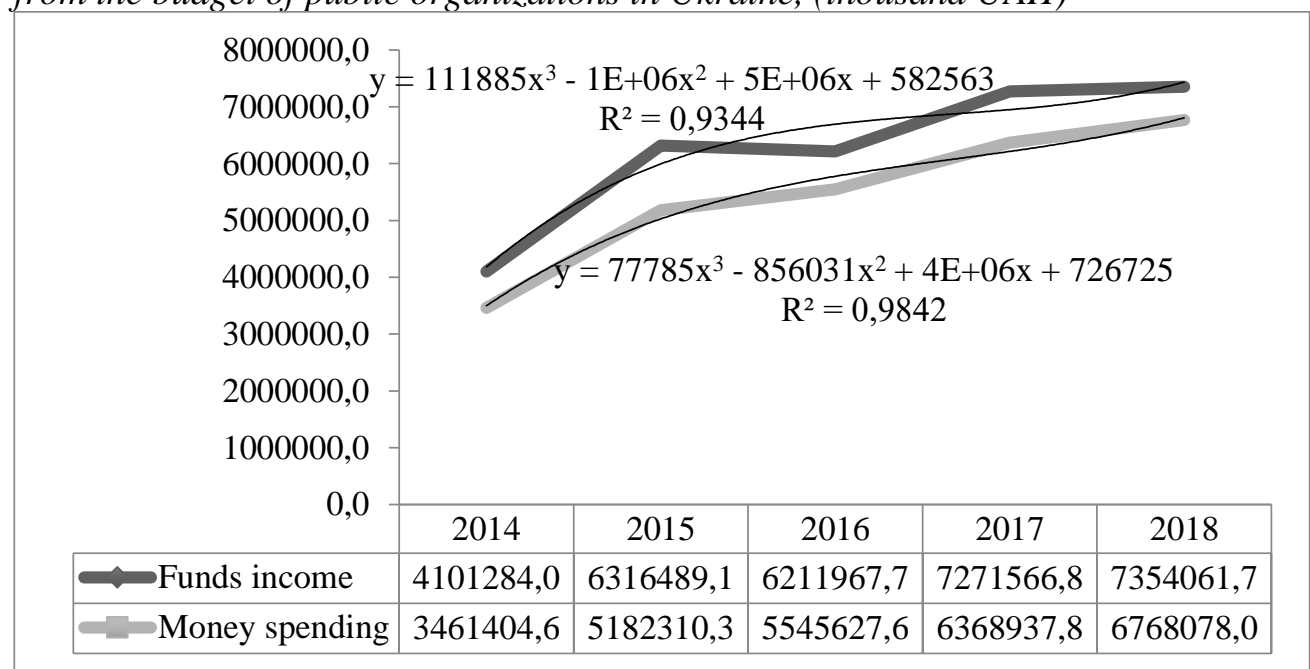

Source: State Statistics Service of Ukraine (2020)

At the same time, the study of the experience of interaction between the authorities and civil society institutions, presented in National Institute for Strategic Studies (2018), gives us reasons to note that today such interaction between the separates involves:

- formation and implementation of advisory bodies in particular public councils, which will function under the authorities and ensure the participation of citizens in the management and controlling of public affairs;

- hold in granular and open public hearings, round tables, public discussions, seminars, conferences concerning determining public opinion on the decisions taken by the authorities;

- $\quad$ public in evolvement in the preparation and celebration of various public holydays, events, as well as anniversaries organized by the authorities;

- signing a number of agreements and memorandum on the specifics of interaction between the authorities and civil society institutions;

- financing the activities of civil society institutions, in clouding public organizations;

- $\quad$ monitoring government bodies and the results of their daily work etc.

As it was noted above, it is necessary to create a special fund in Ukraine which will finance civil society institutions. It should be done in the context of ensuring the development of these institutes.

For example, in Poland funding for the development of civil society institutions is provided by a special and newly created center under the Cabinet of the Prime Minister 
of Poland Narodowy Instytut Wolności-Centrum Rozwoju Społeczeństwa Obywatelskiego (European Economic and Social Committee, 2019).

If we are talking about the functioning of civil society institutions in the European Union, we have to admit that according to U.S. Agency for International Development in 2018 the highest level of resilience to external and internal confrontations had civil society institutions in EU member states such as Hungary, Romania, Bulgaria and Croatia (Figure 3). In Ukraine, the level of stability of civil society institutions is quite high, compared to the member states of the EU and in 2018 is 3.3 points. At the same time, among other countries shown in Figure 3, Estonia has the lowest level of resilience of civil society institutions to external and internal confrontations, which is only 2.1 points.

Figure 3. The level of sustainability of civil society institutions in some EU member states and in Ukraine, points.

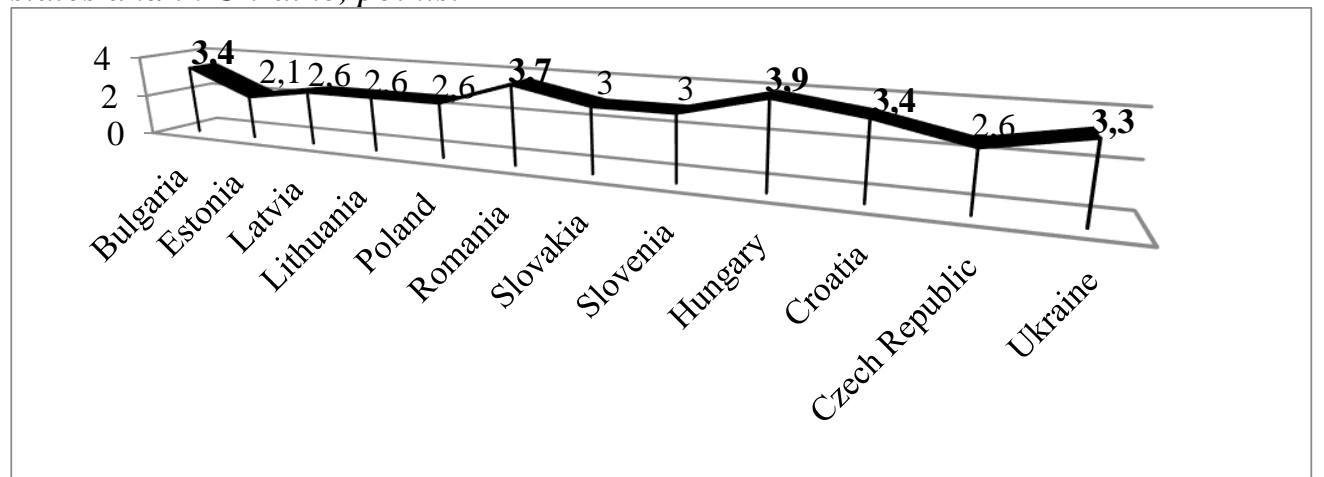

Source: U.S. Agency for International Development (2018).

It is noteworthy that a special international organization Civil Society Europe (CSE) was established in the EU in 2016 (Civil Society Europe, 2016). Its aim is to achieve cooperation between civil society institutions of EU member states and the authorities of these countries.

Studies also show that the system of civil society in Europe includes (National Institute for Strategic Studies, n.d.) 28 European networks of institutions (organizations) of civil society. The main goal of such networks of institutions is to ensure and uphold equality, democracy, solidarity, and inclusiveness of relations between the civil society institutions of European countries and the authorities of these countries.

The Civil Society Europe conducted a survey (Civil Society Europe, 2019). The key issue was to determine the civil position concerning the peculiarities of civil life and law in European countries, as well as far-sighted views on political trends in these countries. The results of the survey have shown that a significant number of respondents in European countries generally have confidence in their freedom of expression, rights to organize assemblies and associations. 
As for the position of civil society institutions regarding civil space, according to the respondents, in Eastern and Central Europe there was a tendency to deteriorate the basic freedoms of civil space. $30 \%$ of respondents say that it is the direct responsibility of each country to ensure the protection of citizens' rights. At the same time, a significant proportion of respondents have noted that the guarantee and promotion of public space should take place at the national level.

Financing of civil society institutions is also an important issue. The respondents stated that financial support should be provided by national governments and institutions of the EU through the usage of appropriate resources. According to the results of the survey, the interaction between the authorities and civil society institutions should take place in the context of organizing the appropriate level of funding in order to increase the level of transparency and access to information on funding.

\section{Discussion and Conclusions}

The study examines the main features of the interaction of government and civil society institutions in the context of implementation of public policy goals. It was found that in Ukraine the interaction between the authorities and civil society institutions in the context of achieving state policy goals involves the participation of civil society institutions in rulemaking and law enforcement functions of the country.

Today civil society institutions, compared to the previous years, are more involved in the implementation of tasks and programs of public policy. However, there are still many obstacles (negative factors) to such cooperation, particularly, low level of trust of civil society institutions in the legitimacy of actions in the system of public authorities; significant corruption among government officials; constant nontransparency of the activities of officials and government officials, improper performance of official duties by government officials and abuse of office (Riepina $e t$ al., 2019).

The results of the study have shown that the country, represented by the authorities and civil society institutions, cannot exist independently of each other. On the one hand, the state has a significant influence on civil society institutions, as it guarantees and ensures the rights of man and nation, as well as establishes the functions of legislative, executive and judicial branches of government, and on the other hand - the development of civil society institutions is not possible under political violence or tyranny. The development can occur only in a state governed by the rule of law and democracy.

The research also proves that mutual trust between the authorities and civil society institutions should be based on the effectiveness of cooperation between them. A public initiative should be the key to a successful dialogue. 
The practice of activity and functioning of civil society institutions in Ukraine demonstrates the growing number of governing bodies of public organizations, which has been observed in recent years. There were 26,630 governing bodies of public organizations in 2018 in Ukraine.

The experience of civil society institutions in the EU shows that in 2018 the highest level of resilience to external and internal confrontations had civil society institutions in EU member states such as Hungary, Romania, Bulgaria and Croatia, and the lowest was observed in Estonia. The level of stability of civil society institutions in Ukraine in comparison with some member states of the EU is quite high.

Summing up the research we have to say that several key aspects in the disclosure of the purpose of the scientific article were studied. These aspects arise during interaction between the authorities and civil society institutions in the context of achieving public policy goals. The study of theoretical and practical features of this article gives grounds to say that cooperation between authorities and civil society institutions in Ukraine is not active enough. There are many reasons why the participation of civil society institutions in achieving public policy goals is often impossible. The research has shown that active interaction between government and civil society institutions can only take place in a democratic and legal state.

It is established that a special international organization (Civil Society Europe, 2019; Coordinating Council for Civil Society Development, 2012) has been established in the EU. It aims to achieve cooperation between civil society institutions of EU member states and the authorities of these countries in the context of equality, democracy, solidarity, and inclusiveness of relations between them.

\section{References:}

Akimova, L.M., Khomiuk, N.L., Bezena, I.M., Lytvynchuk, I.L., Petroye, O. 2020. Planning of socioeconomic development of the territories (experience of European Union). International Journal of Management, 11(4), 638-646.

Bashtannyk, V., Buryk, Z., Kokhan, M., Vlasenko, T., Skryl, V. 2020. Financial, economic, and sustainable development of states within the conditions of industry 4.0.

International Journal of Management, 11(4), 406-413.

Civil Society Europe. 2016. Civic space in Europe survey. Available at: https://civilsocietyeurope.eu/wpcontent/uploads/2019/03/civicspaceineuropesurveyreport_final251015.pdf.

Civil Society Europe. 2019. The European coordination for civil society organizations. Available at: https://civilsocietyeurope.eu.

Coordinating Council for Civil Society Development. 2012. Analysis of the system of state statistics, accounting and evaluation of the development of civil society institutions in Ukraine. Available at: https://civil-rada.in.ua/analiz-sistemi-derzhavno\%D1\%97statistiki-obliku-ta-ocinki-rozvitku-institutiv-gromadyanskogo-suspilstva-vukra\%D1\%97ni. 
Dialogue of Civilizations Research Institute. 2017. Civil society and public institutions in international multi-stakeholder cooperation. Dialogue of Civilizations. Available at: https://doc-research.org/2017/08/civil-society-public-institutions-international-multistakeholder-cooperation-3.

European Economic and Social Committee. 2019. Fundamental rights and rule of law: National developments from a civil society perspective, 2018-2019. Available at: https://www.eesc.europa.eu/sites/default/files/files/frrl_interim_report_20191105.pdf.

Gavkalova, N.L., Gruzd, M.V. 2014. Interaction of public authorities and civil society institutions. Aktual'ni Problem Ekonomiky, 10(160), 281-290.

Karmazina, O.O. 2013. Interaction of public administration bodies with the public in the context of civil society development in Ukraine. Derzhavne Upravlinnia: Teoriia ta Praktyka, 1, 213-219.

Krupnyk, A., Orlova, A. 2020. The state and civil society: an algorithm of interaction. Hromadskyj Prostir. Available at: https://www.prostir.ua/?news=derzhava-ihromadyanske-suspilstvo-alhorytm-vzajemodiji.

Kubiv, S., Bobro, N., Lopushnyak, G., Lenher, Y., Kozhyna, A. 2020. Innovative potential in European countries: Analytical and legal aspects. International Journal of Economics and Business Administration, 8(2), 250-251.

Liasota, A.Ye. 2018. Current state and efficiency of interaction of civil society institutions in Ukraine. Politykus, Naukovyj zhurnal, 1, 54-60.

Melnyk, N.V. 2015. Interaction of civil society institutions with public authorities. Naukovyj Visnyk Lvivskogo Derzhavnogo Universytetu Vnutrishnih Sprav: Seriia Yurydychna, $3,17-25$.

Mesiuk, M. 2018. Interaction of government institutions and civil society in Ukraine in the context of European integration processes. Investytsiyi, Praktyka ta Dosvid, 8, 87-93.

National Institute for Strategic Studies. n.d. The main forms and directions of interaction of public authorities with civil society organizations in Ukraine at the regional level. Available at: http://old2.niss.gov.ua/articles/2896.

Novak-Kalyayeva, L., Raczynski, A. 2019. Multiculturalism as the most constructive approach to the prospects of civilization. National Academy of Managerial Staff of Culture and Arts Herald, 1, 69-73. https://doi.org/10.32461/22263209.1.2019.166539.

Pauly, R., De Rynck, F., Verschuere, B. 2016. The relationship between government and civil society. A neo-Gramscian framework for analysis. European Group for Public Administration, Proceedings. Available at: https://biblio.ugent.be/publication/8065871/file/8065904.pdf.

Pavliuk, K. 2013. Interaction of civil society institutions and public authorities: dialogue through public councils. Efficiency of Public Administration, 37, 235-241.

Riepina, I., Hrybinenko, O., Parieva, N., Parieva, O., Savenko, I., Durbalova, N. 2019. Quantity assessment of the risk of investment projects. International Journal of Recent Technology and Engineering, 8(3), 7256-7260. https://doi.org/10.35940/ijrte.C6338.098319.

Romanenko, Y.O. 2016a. Internet as a means of communication and its influence on public policy formation. Actual Problems of Economics, 1(175), 429-434.

Romanenko, Y.O. 2016b. Place and role of communication in public policy. Actual Problems of Economics, 2(176), 25-31.

Spencer, S., Delvino, N. 2018. Cooperation between government and civil society in the management of migration: Trends, opportunities and challenges in Europe and North America. Compas. Available at: https://www.compas.ox.ac.uk/2018/cooperation- 
between-government-and-civil-society-in-the-management-of-migration-trendsopportunities-and-challenges-in-europe-and-north-america.

State Statistics Service of Ukraine. 2020. Activities of public organizations in Ukraine. Available at: http://www.ukrstat.gov.ua.

U.S. Agency for International Development. 2019. 2018 Civil society organization sustainability index: For Central and Eastern Europe and Eurasia. Available at: https://www.fhi360.org/sites/default/files/media/documents/resource-csosi-2018report-europe-eurasia.pdf.

Verkhovna Rada of Ukraine \& Ministry of Justice of Ukraine. 2011. Interaction of the state and civil society institutions. Available at: https://zakon.rada.gov.ua/laws/show/n0018323-11\#Text. 